\title{
METODE PENGAJARAN BAHASA MANDARIN PRAKTIS UNTUK BIDANG PERHOTELAN DI KAPAL PESIAR
}

\author{
Citra Ayu Novitasari, \\ Prodi Bahasa Mandarin Sekolah Vokasi Universitas Gadjah Mada \\ Email: citraayu@ugm.ac.id, \\ Devy Ayu Riani \\ Prodi Bahasa Mandarin Sekolah Vokasi Universitas Gadjah Mada \\ Email:scddevy@gmail.com
}

\begin{abstract}
:
Mandarin is widely needed in Indonesia nowadays. It is used in many fields, like in service, tourism, education, marine, and journalism industry. Practical Mandarin is definitely required in the working world, for example Mandarin for housekeeping in cruise ship communication. Manpower with additional abilities and skills such as foreign language mastery would improve their competence in the competitive working world. In addition to increasing competencies of the prospective workers, it is also important to provide the best service for the guests. This research will present practical Mandarin teaching methods that can be applied to prospective workers in housekeeping cruise filed. The methods used in this research are library research, field study, and interview.
\end{abstract}

Key word: methods, teaching, Mandarin, housekeeping, cruise ship

Intisari:

Penggunaan bahasa Mandarin saat ini mulai dibutuhkan dalam berbagai bidang di Indonesia, diantaranya bidang industri jasa, pariwisata, pendidikan, perbankan, pelayaran, jurnalistik dan lain sebagainya. Bahasa Mandarin praktis tentunya sangat penting untuk dunia kerja, misalnya bahasa Mandarin pada bidang perhotelan di kapal pesiar. Tenaga kerja dengan kemampuan dan keahlian tambahan seperti kemampuan bahasa asing dapat meningkatkan kompetensi dalam persaingan dunia kerja. Selain menambah kompetensi yang dimiliki calon tenaga kerja, juga penting untuk memberikan pelayanan yang terbaik bagi tamu. Dalam penelitian ini akan dipaparkan mengenai metode-metode pengajaran bahasa Mandarin praktis yang dapat diterapkan bagi calon tenaga kerja, terutama bidang perhotelan di kapal pesiar. Metode yang digunakan dalam penelitian ini antara lain studi pustaka, studi lapangan dan wawancara.

Kata kunci: metode, pengajaran, bahasa Mandarin, perhotelan, kapal pesiar 


\section{Pendahuluan}

Indonesia termasuk negara yang sedang berkembang di Asia. Dengan jumlah penduduk yang besar, yaitu menempati urutan keempat di dunia menjadikan persaingan kerja di Indonesia sangat ketat. Di samping itu, dengan terbukanya pasar bebas menuntut calon tenaga kerja memiliki daya saing dan kompetensi diri yang kuat untuk menghadapi tantangan global. Peningkatan akan mutu dan kemampuan tenaga kerja harus diperhatikan juga oleh Pemerintah. Banyak cara yang dilakukan untuk dapat meningkatkan kualitas calon tenaga kerja, salah satu diantaranya yaitu pembekalan atau pelatihan kemampuan bahasa asing. Dengan bahasa maka komunikasi dapat berjalan dengan lancar. Bahasa asing memegang peranan penting sebagai media komunikasi global. Selain penguasaan bahasa Inggris, dewasa ini penguasaan bahasa asing lain juga sangat dibutuhkan, contohnya bahasa Mandarin. Saat ini bahasa Mandarin ikut memegang peranan dalam komunikasi di dunia. Hal ini dikarenakan banyaknya jumlah penutur bahasa ini serta majunya perkonomian Tiongkok menjadi salah satu alasan mengapa bahasa Mandarin mulai diakui sebagai bahasa Internasional setelah bahasa Inggris.

Seiring dengan semakin banyaknya investor dari Tiongkok yang berinvestasi di Indonesia, lembaga penyedia lowongan pekerjaan seringkali menambahkan syarat khusus seperti menguasai lebih dari satu bahasa asing untuk dapat diterima di bidang pekerjaan yang dibutuhkan.

Pengajaran bahasa asing untuk calon tenaga kerja berbeda dengan pengajaran di institusi pendidikan formal seperti Sekolah Menengah maupun di Universitas. Bagi calon tenaga kerja, bahasa yang praktis dan dapat dikuasai dalam waktu yang singkat merupakan hal yang sangat dibutuhkan. Oleh karena itu pengajaran yang diberikan tentunya harus ditekankan pada metode-metode yang sesuai dengan kebutuhan tenaga kerja sehingga dapat langsung diterapkan di dunia kerja. Dalam hal ini bahasa Mandarin dengan metode pengajaran praktis dapat digunakan untuk meningkatkan kemampuan dan kompetensi saat calon tenaga kerja menghadapi dunia kerja nyata. Pengajaran yang dipersiapkan juga memerlukan inovasi agar tidak monoton. Karena waktu belajar yang terbatas, 
maka diharapkan pengajar juga dapat memanfaatkan waktu belajar mengajar dengan seefektif mungkin dengan menerapkan metode praktis dan disertai dengan praktek atau latihan-latihan. Menurut Cronbach dalam bukunya yang berjudul Educational Psycology dikemukakan bahwa: "Learning is shown by change in behaviour as a result of experience. " Belajar yang efektif adalah melalui pengalaman. Dalam proses belajar, seseorang berinteraksi langsung dengan objek belajar dengan menggunakan semua alat indranya. Sedangkan Howard L. Kingsley dalam buku Psikologi Belajar (Ahmadi dan Widodo Supriyono, 2013, hal. 127) mengatakan: Learning is the process by which behavior (in the broader sense) is originated or changed through practice or training. Dapat diartikan bahwa belajar adalah proses di mana tingkah laku (dalam arti luas) ditimbulkan atau diubah melalui praktek atau latihan.

Dalam mengembangkan kemampuan intelektual tenaga kerja, pendidikan dan pelatihan menjadi hal yang utama untuk membekali diri. Seseorang akan mampu meningkatkan kemampuan kognitif, efektif, dan psikomotoriknya melalui pendidikan. $\mathrm{Di}$ samping itu perkembangan sosial-budaya yang berlangsung dengan cepat telah memberikan tantangan kepada setiap individu, sehingga individu senantiasa ditantang untuk terus selalu belajar agar dapat menyesuaikan diri sebaik-baiknya. (Ahmadi \& Supriyono, 2013, hal. 105).

Kapal pesiar sebagai salah satu industri yang menyediakan paket liburan mewah terus mengalami perkembangan. Destinasi wisata yang awalnya hanya tersedia untuk benua Eropa dan Amerika kini telah membidik pasar Asia. Berdasarkan wawancara dengan Muhari, salah satu awal kapal Mediterranean Shipping Cruises yang melayani rute paket wisata Eropa dan telah bekerja di kapal tersebut dari tahun 2010 mengatakan bahwa pada tahun 2010, wisatawan dari Tiongkok yang mengikuti wisata kapal pesiar ini sebanyak lima puluh orang. Tahun 2011 sampai 2012 mengalami kenaikan per cruise menjadi seratus orang. Pada tahun 2013 sampai 2015 jumlah wisatawan dari Tiongkok naik lagi menjadi dua ratus sampai lima ratus orang per cruise. Dilihat dari makin banyaknya wisatawan yang berasal Tiongkok yang mengikuti wisata ini, maka kebutuhan tenaga kerja yang dapat berkomunikasi dengan bahasa Mandarin 
juga semakin dicari dan semakin meningkat pula. Gaji yang lumayan besar menjadi daya tarik bagi calon tenaga kerja baik di dalam maupun di luar negeri. Peluang ini harus dimanfaatkan dengan sebaik-baiknya oleh calon tenaga kerja Indonesia. Hal ini menjadi sebuah persaingan yang kuat jika tidak dimanfaatkan dengan baik, karena tenaga kerja dari negara lain pun akan berlomba-lomba untuk menempati posisi ini. Dengan menguasai bahasa Mandarin maka akan dapat digunakan sebagai bahasa penunjang untuk berkomunikasi terutama dalam melayani tamu serta berinteraksi dengan pekerja yang sebagian besar adalah dari Asia, tidak terkecuali dari Tiongkok.

\section{Metode}

Data dari penelitian ini dikumpulkan dengan metode studi pustaka, studi lapangan dan wawancara. Studi pustaka dilakukan dengan mencari data dan membaca dari buku-buku, internet serta jurnal. Studi lapangan dan wawancara dilakukan di Sekolah Perhotelan Miami Fleet Yogyakarta melalui program magang selama dua bulan (Januari - Maret 2017). Pada saat magang, peneliti melibatkan diri menjadi pengajar di Sekolah Perhotelan Miami
Fleet Yogyakarta. Wawancara dilakukan dengan cara tanya jawab langsung kepada direktur Miami Fleet Yogyakarta pada tanggal 7 maret 2017. Wawancara diajukan dengan menanyakan pertanyaan mengenai Sekolah Perhotelan Miami Fleet, latar belakang dibukanya kelas bahasa Mandarin dan peranan bahasa Mandarin untuk meningkatkan kualitas calon tenaga kerja terutama di bidang perhotelan di kapal pesiar. Disamping itu, wawancara juga dilakukan dengan Muhari pada tanggal 13 Agustus 2017. Muhari adalah salah satu awak kapal pesiar yang telah bekerja di kapal pesiar Mediterranean Shipping Cruises selama kurang lebih enam tahun. Pertanyaan yang diajukan tentang kebutuhan kapal pesiar terhadap awak kapal yang mampu berbahasa Mandarin.

\section{Hasil dan Pembahasan}

Sekolah Perhotelan dan Kapal Pesiar Miami Fleet adalah lembaga yang menyelenggarakan pelatihan bagi tenaga kerja yang ingin berkarir di kapal pesiar, dan telah sukses melatih serta menempatkan tenaga kerja di beberapa perhotelan darat maupun kapal pesiar terutama di bidang hospitality industry. Lembaga pelatihan ini berdiri sejak tahun 2004 dan bergabung menjadi satu Jurnal Lingua Aplicata Volume 1, Nomor 1 September 2017 
dengan PT. Quantum Job sebagai perusahaan yang bergerak di bidang penyaluran tenaga kerja, terutama di bidang perhotelan dan kapal pesiar. PT. Quantum Job secara resmi dikenal sebagai lembaga pelatihan dan perekrutan tenaga kerja yang selanjutnya berkembang menjadi Sekolah Perhotelan Kapal Pesiar Miami Fleet Yogyakarta. Sekolah Perhotelan Kapal Pesiar Miami Fleet Yogyakarta beralamat di Jl. Perintis Kemerdekaan nomor 85 Yogyakarta. Sekolah ini berdiri di atas tanah seluas $800 \mathrm{~m}^{2}$ dengan memiliki empat ruang kelas yang dibuat menyerupai ruangan yang ada di dalam kapal pesiar. Setiap kelas diberi nama sesuai dengan nama dek di kapal pesiar Carnival, yaitu Fantassy, Spirit, Destiny, dan Conquest. Proses pendidikan dan pelatihan di sekolah ini membutuhkan waktu tiga bulan. Namun terkadang tidak sampai tiga bulan, beberapa siswa yang mengikuti rekruitmen dapat lolos seleksi wawancara serta sudah dapat mengurus dokumen dan berangkat ke kapal.

Menurut MT Ritonga dan Yoga Firdaus (2007, hal. 2) mengemukakan bahwa tenaga kerja adalah penduduk dalam usia kerja yang siap melakukan pekerjaan, antara lain orang yang sudah bekerja, mencari pekerjaan, bersekolah, dan mengurus rumah tangga. Sedangkan Oemar (2000) berpendapat bahwa tenaga kerja yang berkualitas adalah yang memiliki karakteristik keterampilan bekerja dan wawasan pengetahuan yang luas, profesional, produktif, dan memiliki etos kerja yang tinggi.

Berdasarkan wawancara dengan Andre Hermawan sebagai direktur dari PT. Quantum Job, keterampilan bahasa asing yang dimiliki tenaga kerja sangat membantu ketika wawancara atau perekrutan tenaga kerja. Human resourches development (HRD) dari salah satu kapal pesiar ternama, Costa Cruise Line, mengungkapkan kebutuhan kapal pesiar yang berlayar di Asia terhadap tenaga kerja yang dapat berbicara bahasa Mandarin masih cukup besar. Cook helper dan waiter kapal pesiar sebagai salah satu posisi yang ramai diminati oleh tenaga kerja Indonesia sekaligus lowongan yang paling banyak diberikan oleh kapal pesiar. Oleh karena itu dengan menambahkan kualifikasi tambahan untuk dapat diterima secara cepat yaitu dengan penguasaan terhadap bahasa Mandarin. Posisi purser atau resepsionis dan waiter yang kesehariannya bertemu dengan wisatawan di kapal pesiar akan lebih 
mudah diterima di kapal pesiar jika dapat menguasi bahasa asing selain bahasa Inggris, bahkan hal tersebut sudah menjadi syarat utama bagi beberapa kapal pesiar yang berlayar di wilayah Asia. Dengan memiliki keterampilan bahasa Mandarin, posisi demikian dapat dijalani dengan lebih mudah, terutama jika yang dihadapi adalah wisatawan dari Tiongkok.

Menu unggulan yang disediakan di bagian dapur kapal pesiar adalah Chinese food, oleh karena itu pekerja dapur tersebut langsung didatangkan dari Tiongkok. Menu, resep dan istilah yang digunakan tentu saja dengan bahasa Mandarin juga, sehingga kemampuan bahasa Mandarin menjadi hal yang penting untuk posisi tersebut.

Berdasarkan uraian di atas, dapat disimpulkan bahwa penguasaan akan bahasa Mandarin pada kapal pesiar utamanya yang berlayar di Asia sangat dibutuhkan. Dengan menguasai bahasa Mandarin, para pekerja dapat berinteraksi dan berkomunikasi dengan baik sehingga dapat menjadi penghubung, baik dengan tamu ataupun sesama pekerja lain yang berasal dari Asia.
Pengajaran bahasa Mandarin untuk calon tenaga kerja lebih diutamakan pada kemampuan Berbicara dan Menyimak. Hal ini dikarenakan pengajaran bahasa Mandarin diberikan dalam waktu yang singkat, yaitu selama dua bulan dengan perkuliahan satu minggu sebanyak lima kali tatap muka selama kurang lebih tiga sampai empat jam per hari. Oleh karena itu pembelajaran praktis harus digunakan dengan seefektif mungkin agar calon tenaga kerja dapat mudah dan cepat memahami materi dan yang paling utama ialah dapat berkomunikasi dengan bahasa Mandarin dengan baik dan lancar. Materi yang diberikan dalam pengajaran di Miami Fleet meliputi kosa kata, dialog atau percakapan, ilustrasi, ungkapan, dan tata bahasa dasar yang disesuaikan dengan kebutuhan perhotelan dan kapal pesiar seperti pada bagian front office, waiter, housekeeping, room service, dan cooking. Penguasaan Hanzi atau Chinese character tidak diajarkan, mengingat keterbatasan waktu. Sumber materi yang dipergunakan dalam pengajaran ini yaitu beberapa buku bahasa Mandarin yang berhubungan dengan bidang perhotelan, materi yang diambil dari internet, youtube dan pengembangan materi yang 
disusun sendiri oleh penulis. Isi materi pembelajaran yang digunakan antara lain kosa kata, kalimat maupun dialog yang berhubungan dengan greeting, angka, waktu (tanggal, bulan, tahun dan jam), cara mengucapkan terimakasih dan meminta maaf, menawarkan bantuan, arah, nama makanan dan minuman, nama sayur dan buah-buahan, macam makanan Chinese food dan cara membuatnya, nama peralatan makan dan alat-alat dapur, nama alat housekeeping, menerima telepon dari tamu, menjawab telepon untuk menerima pemesanan makanan, menjawab komplain tamu, menjelaskan tentang menu dan harga, dan lain sebagainya.

Pada awal pertemuan akan lebih baik jika diberikan penjelasan mengenai materi apa saja yang akan dipelajari selama pelatihan. Sehingga siswa mempunyai gambaran yang jelas tentang pengetahuan yang akan dikuasai serta arah pembelajaran. Metode pengajaran yang digunakan dalam pembelajaran ini adalah metode ceramah, metode word power, metode deskripsi dan diskusi, aplikasi smart phone, metode menyimak berbicara, metode simulasi dan role play, metode review dan yang terakhir adalah evaluasi. Metode-metode tersebut digunakan secara bergantian sesuai dengan materi yang akan diberikan. Menurut Kamus Besar bahasa Indonesia (2005) metode merupakan cara teratur yang digunakan untuk melaksanakan suatu pekerjaan agar tercapai sesuai dengan yang dikehendaki; metode adalah kerja yang bersistem untuk memudahkan pelaksanaan suatu kegiatan guna mencapai tujuan yang ditentukan. Sedangkan menurut Uno (2015, hal. 2) mengatakan bahwa metode pembelajaran merupakan cara yang digunakan guru, yang dalam menjalankan fungsinya merupakan alat untuk mencapai tujuan pembelajaran. Dengan menggunakan metode yang tepat maka tujuan dari pembelajaran akan tercapai.

\section{Metode Ceramah}

Metode ini merupakan suatu cara mengajar yang digunakan untuk menyampaikan keterangan atau informasi atau uraian tentang suatu pokok persoalan serta masalah secara lisan (Roestiyah, 2001). Metode ini memiliki kekurangan dan kelebihan. Contoh kekurangannya yaitu jika isi materi terlalu banyak akan membuat siswa merasa bosan. Oleh karena itu, untuk mengatasinya metode ini dapat digabungkan dengan metode latihan. 
Penerapan metode ini dalam dari penutur asli, gambar untuk ilustrasi pembelajaran bahasa Mandarin misalnya, metode ini dapat dilakukan saat pengenalan pembelajaran lafal dan nada atau pada setiap awal pemberian materi baru. Agar terjadi interaksi aktif antara pengajar dan siswa, maka metode ini dapat digabungkan juga dengan dengan metode tanya jawab. Setelah pengajar memberikan penjelasan, pengajar dapat menyiapkan contoh-contoh, dalam hal ini misalnya pelafalan dan nada. Siswa dapat diminta untuk langsung mengucapkan dan mempraktekkan baik pelafalan (konsonan dan vokal), nada, atau gabungan dari keduanya. Penjelasan tentang pelafan Hanyu Pinyin dan nada sangat penting, karena materi ini merupakan dasar dari pengucapan. Apabila bagian dasar dari pelafalan terdapat kesalahan, maka tugas pengajar adalah langsung mengoreksi dan memberi contoh pelafalan atau nada yang tepat. Hal ini juga berlaku saat memberikan materi yang lain, contohnya saat diberikan materi tentang greeting, dialog dan lain sebagainya. Agar pembelajaran lebih menarik, maka dapat digunakan media pendukung pembelajaran misalnya video dari youtube, compact disk (CD) atau rekaman dan lain-lain. Hal ini juga disampaikan oleh Pribadi (2011) yang menyatakan bahwa kombinasi yang tepat dalam memanfaatkan metode dan media pembelajaran dapat membantu guru dan instruktur untuk menciptakan pembelajaran sukses.

\section{Metode Word Power}

Word power berarti metode kekuatan kata. Metode ini menekankan pada daya ingat siswa untuk menghafalkan kosa kata. Metode ini sebelumnya diberikan oleh instruktur bahasa Inggris untuk siswa Miami Fleet Yogyakarta. Penulis menerapkan metode Word Power dengan pertimbangan hafalan kosakata merupakan hal yang cukup efektif dalam menguasai bahasa asing, dalam hal ini bahasa Mandarin. Dalam satu hari, pengajar dapat memberikan taget kepada siswa untuk menghafalkan sejumlah kosa kata yang telah dipelajari. Pada hari berikutnya siswa satu persatu diminta untuk mengucapkan kosa kata yang telah dihafalkan. Jumlah hafalan kosa kata tergantung dari kebutuhan waktu pelatihan, semakin pendek waktu pelatihan maka kosa kata yang dihafalkan siswa per harinya pun juga semakin Jurnal Lingua Aplicata Volume 1, Nomor 1 September 2017 
banyak. Word Power dapat dipilih dari kumpulan kosa kata yang sering digunakan dalam kehidupan sehari-hari maupun yang berhubungan dengan bidang kerja dan dapat disesuaikan juga dengan kebutuhan siswa. Kosakata tersebut kemudian diterjemahkan ke dalam bahasa Mandarin. Pada metode ini dapat dilakukan pada saat awal atau sebelum kelas berakhir. Selain dapat melatih daya ingat siswa terhadap materi yang telah lalu, juga dapat meningkatkan disiplin siswa karena metode ini membuat siswa mau tidak mau setiap hari belajar dan membuka catatan pelajaran. Disamping itu, metode ini dapat merangsang siswa untuk dapat mengimplementasikan kosakata tersebut hingga menjadi kalimat ataupun dialog pendek. Hafalan Word Power ini dapat diterapkan dalam pembelajaran bahasa asing secara umum dan segala usia, dengan menyesuaikan kebutuhan dan tujuan pembelajar masing-masing.

\section{Metode Deskripsi dan Diskusi}

Deskripsi merupakan pemaparan atau penggambaran dengan kata-kata secara jelas dan terperinci (KBBI, 2005). Deskripsi berperan penting dalam membentuk imajinasi siswa dalam mendeskripsikan suatu situasi. Pengajar secara berkala memberikan gambar yang menyangkut dengan bab yang sedang dibahas. Gambar yang mendukung pembelajaran sangat mudah diperoleh dari internet, majalah, koran dan media lainnya. Pemilihan gambar juga harus tepat sesuai materi pembelajaran serta gambar yang menarik. Selain memberikan gambar untuk didesripsikan, juga dapat diberikan sedikit stimulan melalui Clue Word atau petunjuk kata. Selain membuat diskripsi dengan gambar, siswa juga diminta untuk membuat percakapan dan mempraktikannya.

Metode diskusi adalah proses membahas suatu persoalan dengan melibatkan banyak orang, di mana hasil dari pembahasan tersebut akan menjadi alternatif jawaban dalam memecahkan persoalan. Dalam hal ini orang-orang yang terlibat di dalamnya mengemukakan pandangannya sendirisendiri terhadap persoalan yang dilontarkan. Dalam pengajaran bahasa Mandarin, penerapan metode ini misalnya saat pengajar memberikan gambar resepsionis hotel, siswa dapat diminta untuk berdiskusi dan mengucapkan kalimat yang berhubungan dengan gambar tersebut. Siswa juga bisa 
diminta untuk mengucapkan kalimat yang saling berhubungan antara siswa satu dengan yang siswa yang lain, atau dapat juga beberapa orang berdiskusi membuat dialog pendek seputar gambar tersebut. Kelemahan metode ini, jika pengajar tidak membatasi waktu, maka akan banyak memakan waktu di kelas. Dengan demikian saat pengajar menerapkan metode ini harus memberikan batasan waktu tertentu. Kelebihan dari metode ini ialah siswa merasa tertantang untuk berbicara dan mengungkapkan isi pikirannya, kreatif menggunakan kosa kata yang telah dipelajari, sehingga dapat meningkatkan kemampuan dalam hal berbicara. Siswa yang pasif di kelas pun dapat ikut aktif dan berpartisipasi dalam kegiatan ini.

\section{Metode Aplikasi Smartphone}

Seiring berkembangnya teknologi saat ini, media pembelajaran dapat diakses secara mudah, sumber informasi tidak hanya melalui buku atau media cetak saja, namun dapat ditemukan dalam aplikasi yang terdapat dalam smartphone. Pembelajaran modern seperti penggunaan smartphone ini juga diterapkan dalam pengajaran bahasa Mandarin di Miami Fleet Yogyakarta. Dewasa ini rata-rata siswa telah memiliki smartphone sehingga materi dapat diperoleh dari aplikasi di smartphone masing-masing. Aplikasi smartphone yang dapat digunakan dalam pembelajaran berbahasa Mandarin diantaranya Learn Chinese, Everyday Speak Chinese, Chinese Recipes, Chinese Fun, Listen Chinese, Hanping, Pleco, Youtube dan masih banyak lagi. Aplikasi Hanping dan Pleco adalah kamus elektronik bahasa Mandarin-Inggris, Inggris-Mandarin. Penggunaan aplikasi kamus ini dapat membantu siswa dalam mencari arti baik kosa kata maupun kalimat. Tujuan diberikannya metode ini agar siswa dapat berlatih dan belajar secara mandiri di luar pelajaran bahasa Mandarin. Dengan demikian selain kosa kata akan bertambah, juga dapat melatih kemampuan menyimak dan berbicara siswa. Metode ini juga dirasa praktis karena kapanpun dan dimanapun siswa dapat belajar dan menambah perbendaharaan kosa kata, kalimat maupun melancarkan dalam berbicara bahasa Mandarin.

\section{Metode Menyimak dan Berbicara}

Metode Menyimak dan Berbicara merupakan dua komponen penting dalam penguasaan kemampuan berbahasa Mandarin. Metode menyimak 
diterapkan sebagai bentuk praktik dari setiap kosakata yang telah dihafalkan sekaligus review, maka diberikan latihan mendengarkan baik itu mendengarkan rekaman percakapan dari compact disk (CD), youtube, aplikasi smartphone, maupun dari pengajar sendiri yang membacakan teks, dikte, maupun percakapan. Siswa diminta untuk mendengarkan kemudian menceritakan kembali isi dari percakapan yang telah didengar secara langsung dari $C D$, youtube ataupun yang dibacakan oleh pengajar. Metode menyimak ini sekaligus untuk melatih kemampuan berbicara siswa. Metode berbicara juga dapat menggunakan dialog antar siswa dengan materi yang ditentukan pengajar, tanya jawab antara pengajar dengan siswa, maupun dengan bantuan media pendukung pelajaran yang lain.

\section{Metode Review}

Metode ini merupakan metode mengulang dengan tujuan untuk merangsang daya ingat siswa dalam mengingat kembali pelajaran yang telah diajarkan melalui tanya jawab secara spontan antara pengajar dengan siswa maupun siswa dengan siswa. Metode ini juga dapat dilakukan dengan membagi siswa dalam kelompok kecil kemudian antara kelompok satu dengan yang lain saling bergantian untuk mengajukan pertanyaan dan menjawabnya.

Pada bidang perhotelan kapal pesiar, materi tentang pelayanan, restoran, dan cooking lebih ditekankan, mengingat siswa yang belajar bahasa Mandarin di Sekolah Perhotelan Kapal Pesiar Miami Fleet merupakan tenaga kerja yang akan bekerja di bidang perhotelan kapal pesiar. Daftar kosakata seperti greeting, jenis-jenis hidangan dan minuman, buah dan sayuran, peralatan dapur, peralatan housekeeping di review setiap kali tatap muka. Disamping itu dialog atau kalimat pendek yang berhubungan dengan pelayanan di restoran juga sering diulang. Sedangkan untuk kosakata umum seperti angka, jam, hari dan tanggal, arah, dan lain-lain diberikan di sela-sela pelajaran. Manfaat metode ini selain dapat menyegarkan kembali ingatan siswa tentang materi yang telah diberikan, juga dapat mengetahui tingkat kemampuan siswa dan penguasaan terhadap materi.

\section{Metode Simulasi dan Role Play}

Simulasi merupakan metode pelatihan yang meragakan sesuatu di bentuk tiruan yang mirip dengan keadaan yang sesungguhnya atau penggambaran 
suatu sistem atau proses dengan peragaan berupa model statistik atau pemeranan(KBBI, 2005). Metode ini digabungkan dengan bermain peranan karena dengan memainkan peranan tersebut siswa memperoleh suatu pengertian yang lebih baik dari orang yang dimainkannya, serta motif yang mempengaruhi tingkah lakunya dan biasanya permainan ini diarahkan kepada pengembangan afektif. (Ahmadi \& Widodo Supriono, 2013, hal.166). Dengan menerapkan metode ini dalam pembelajaran bahasa Mandarin dapat membuat siswa lebih aktif dan turut berpartisipasi dalam kegiatan pembelajaran. Kemampuan bahasa Mandarin terutama dalam hal berbicara lebih dapat berkembang dengan maksimal. Metode simulasi yang diterapkan di Sekolah Perhotelan dan Kapal Pesiar Miami Fleet yaitu dengan praktek langsung di ruang kelas yang telah didesain sesuai dengan kondisi yang ada di kapal pesiar, misalnya housekeeping laboratory, kitchen, dining hall, bar, vessel storage dan lain sebagainya.

\section{Evaluasi}

Evaluasi merupakan pemberian nilai terhadap hasil pembelajaran yang telah dilakukan. Zainul dan Nasution
(2001, hal. 73) mengungkapkan bahwa evaluasi merupakan proses menggambarkan, memperoleh, dan menyajikan informasi yang berguna untuk merumuskan suatu alternatif keputusan. Sedangkan menurut Iskandarwassid dan Dadang (2008, hal.289) menyatakan pengertian tes apabila dikaitkan dengan pelaksanaan proses pembelajaran di kelas, maka tes adalah suatu alat yang digunakan oleh pengajar untuk memperoleh informasi tentang keberhasilan peserta didik dalam memahami suatu materi yang telah diberikan oleh pengajar. Dalam penerapan metode ini pengajar akan melaksanakan dua kegiatan yaitu mengukur kemampuan peserta didik dan mengukur keberhasilan programprogram pengajaran. Evaluasi pembelajaran bahasa Mandarin dilakukan dengan memberikan tes berkala setiap satu bab yang telah diajarkan. Tes tersebut yaitu tes penguasaan kosa kata yang dilakukan melalui dikte ataupun menyimak kemudian mengulangi ucapan pengajar, tes penguasaan kosa kata, penggunaan kosa kata dalam kalimat serta tata bahasa Mandarin, tes permainan peran misalnya dialog antara tamu dengan pelayan, dialog sesama 
koki, waiters dengan tamu, dialog menawarkan bantuan dan lain sebagainya.

Setiap metode dalam pengajaran ini dapat digabungkan dengan metode yang lain, misalnya metode review dengan metode tanya jawab, metode ceramah dengan metode latihan, metode deskripsi digabung dengan metode diskusi atau dialog dan lain sebagainya. Metode-metode tersebut dapat memacu siswa untuk semakin mengembangkan potensi dan kemampuan diri calon tenaga kerja melalui berbagai macam praktik penguasaan bahasa Mandarin.

\section{Kesimpulan}

Persaingan global menuntut seseorang untuk meningkatkan kualitas diri baik dalam hardskill maupun softskill. Dengan softkill yang baik kita mampu berkomunikasi dan bekerjasama dengan orang lain. Komunikasi dalam dunia kerja lintas negara dapat ditunjang dengan kemampuan menguasai bahasa asing, salah satunya adalah bahasa Mandarin. Dengan menguasai bahasa Mandarin dapat meningkatkan nilai jual di dunia kerja, misalnya pada bidang kapal pesiar. Wisata kapal pesiar semakin lama semakin berkembang, baik dari segi peminat maupun rute yang dilaluinya.
Selain pelayaran dengan tujuan Eropa, juga mulai banyak kapal pesiar dengan rute tujuan ke Asia. Melihat perkembangan tersebut maka makin banyak pula dibutuhkan tenaga kerja yang selain mempunyai kemampuan dalam bidang perhotelan juga mempunyai keahlian berkomunikasi dengan bahasa selain bahasa Inggris. Karena bahasa Mandarin merupakan salah satu bahasa yang paling banyak digunakan oleh masyarakat di dunia, maka penguasaan bahasa ini di era global sangatlah dibutuhkan dalam berbagai bidang, tak terkecuali bidang perhotelan di kapan pesiar.

Sekolah Perhotelan dan Kapal Pesiar Miami Fleet Yogyakarta mempersiapkan calon tenaga kerja dengan bekal kemampuan yang beragam, salah satunya bahasa Mandarin. Dalam pengajaran bahasa Mandarin dibutuhkan pembelajaran yang praktis dengan metode-metode yang sesuai dan dibutuhkan oleh calon tenaga kerja di kapal pesiar. Metode yang dapat diterapkan adalah metode ceramah, metode word power, metode deskripsi dan diskusi, metode aplikasi smartphone, metode menyimak berbicara, metode review dan evaluasi. Metode-metode 
tersebut dinilai dapat meningkatkan kemampuan siswa Sekolah Perhotelan dan Kapal Pesiar Miami Fleet Yogyakarta dalam penguasaan kosa kata, berbicara, mendengarkan serta mengaplikasikannya dalam kalimat.

\section{Daftar Pustaka}

Ahmadi, Abu \& Widodo Supriyono. 2013. Psikologi Belajar. Jakarta: Rineka Cipta

Hamalik, Oemar. 2005. Pengembangan Sumber Daya Manusia (Manajemen Pelatihan Ketenagakerjaan ) Pendekatan Terpadu. Jakarta: PT. Bumi Aksara.

Hamid, Moh. Sholeh. 2013. Metode Edutaintment. Yogyakarta: Diva Press

Iskandarwassid \& Dadang. 2011. Strategi Pembelajaran Bahasa. Bandung: PT Remaja Rosdakarya Offset.

MT, Ritonga, Yoga Firdaus, 2007. Pengertian Tenaga Kerja dan Angkatan. (Online).

http://muawanahcius.blogspot.co $\mathrm{m}$

Pusat Bahasa Departemen Pendidikan Nasional. Kamus Besar Bahasa
Indonesia. 2005. Jakarta: Balai Pustaka

Pradono, Sudono Noto. 2011. Bahasa Mandarin Praktis untuk Resto \& Hotel. Yogyakarta : ANDI.

Pribadi, A. Benny. 2011. Model Assure untuk Mendesain Pembelajaran Sukses. Jakarta:Dian Rakyat

Riani, Devi Ayu. 2017. Bahasa Mandarin Untuk Calon Tenaga Kerja (Pengajaran Bahasa Mandarin di Sekolah Kapal Pesiar Miami Fleet Yogyakarta). Tugas Akhir tidak diterbitkan. Yogyakarta: Sekolah Vokasi Universitas Gadjah Mada.

Scurfield, Elizabeth dan Song, Lianyi. 2000. Bahasa Mandarin Untuk Pemula. Jakarta : PT. Gramedia Widiasarana Indonesia.

Tjahjadi, Lilisagita. 2007. Terampil Berbahasa Mandarin. Jawa tengah : Intan sejati.

Uno, Hamzah B. 2015. Model Pembelajaran. Jakarta: Bumi Aksara

Wiantara, I Gusti Nyoman. 2014. Cruise Line Knowledge . Yogyakarta: Penerbit Andi

Zainul \& Nasution. 2001. Penilaian Hasil belajar. Jakarta: Dirjen Dikti. Internet:

http://www.decodemandarinchinese.com/

\section{http://wordoor-chinese.tumblr.com/}

http://www.hanbridgemandarin.com

http://www.jogjabagus.com 


\section{Lampiran}
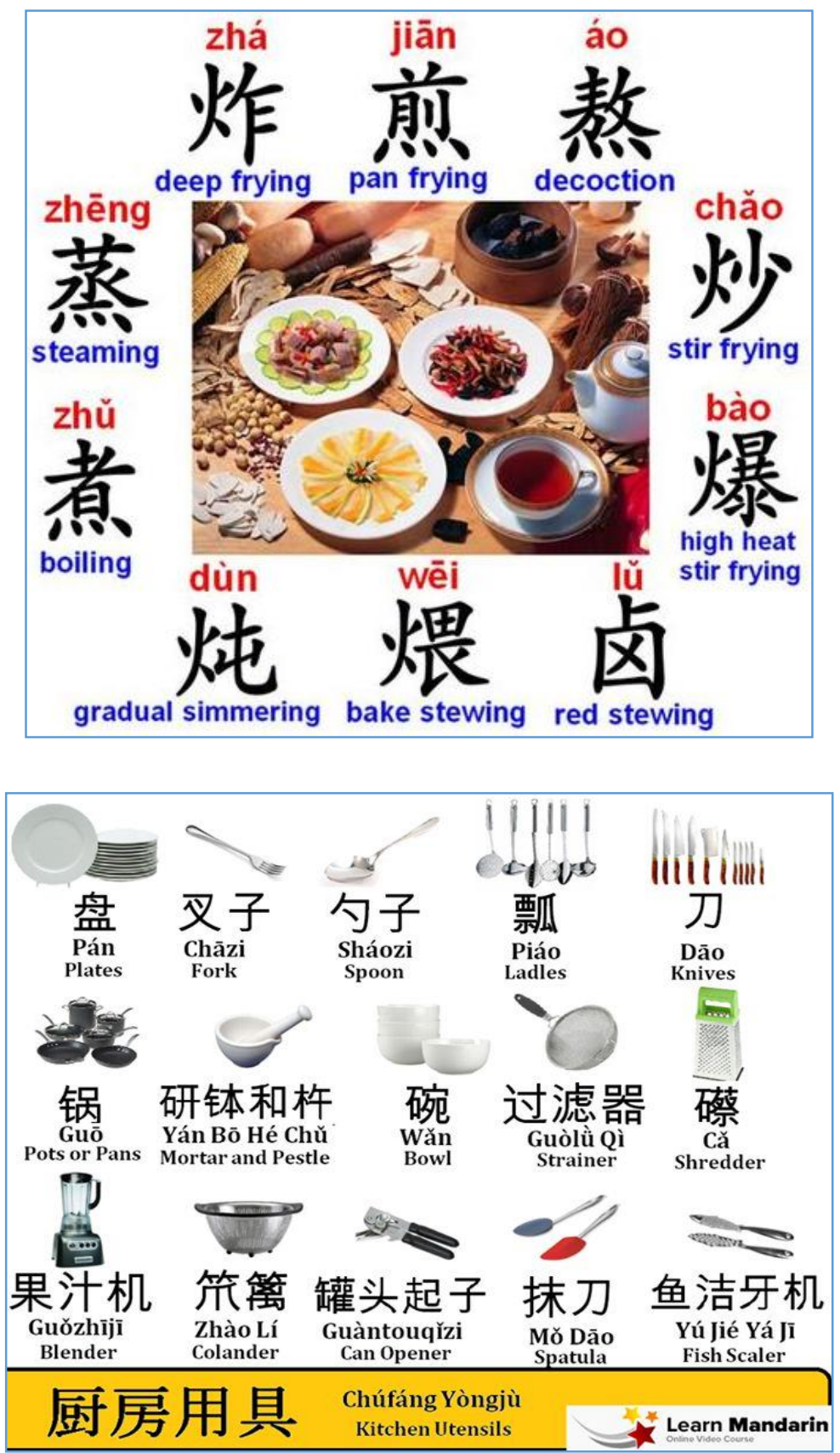

Gambar 1. Istilah cara memasak dan nama peralatan dapur dalam bahasa Mandarin Sumber: (sumber: http://www.decodemandarinchinese.com/) 


yī píng niú năi
一瓶牛奶
a lottle of milk
yī tiáo miàn bão
a loaf of bread
$\begin{aligned} & \text { yī kuài qiăo kè lì chá } \\ & \text { 一块巧克力 } \\ & \text { a bar of chocolate }\end{aligned}$

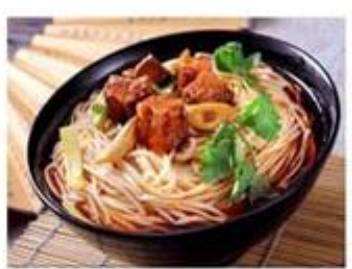

面条 miàn tiáo noodles

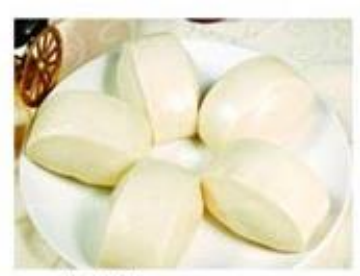

馒头 mántou steamed bread

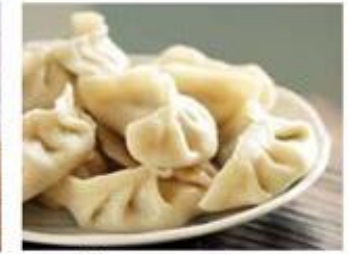

饺子 jiǎozi dumplings

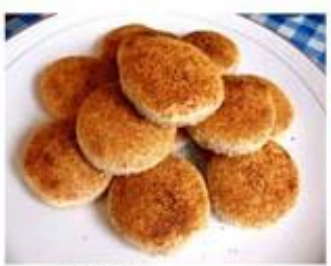

烧饼 shāobìng sesame seed cake

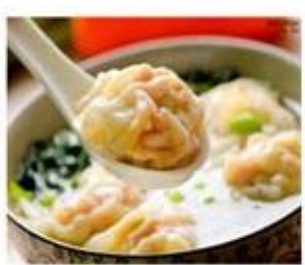

馄饨 húntun wontons

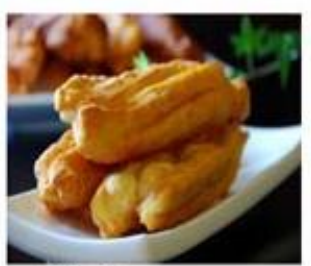

油条 yóutiáo fried bread stick
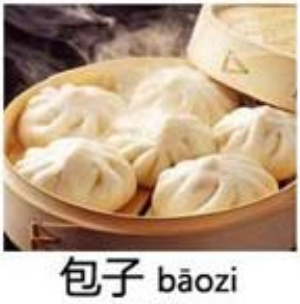

stuffed buns

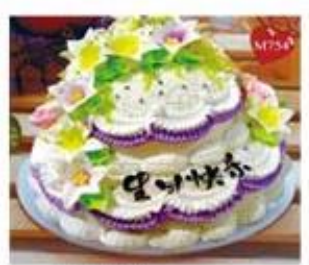

蛋糕 dàngāo cake

Gambar 2. Contoh nama-nama makanan dan minuman dalam bahasa Mandarin Sumber: (sumber : http://www.hanbridgemandarin.com) 

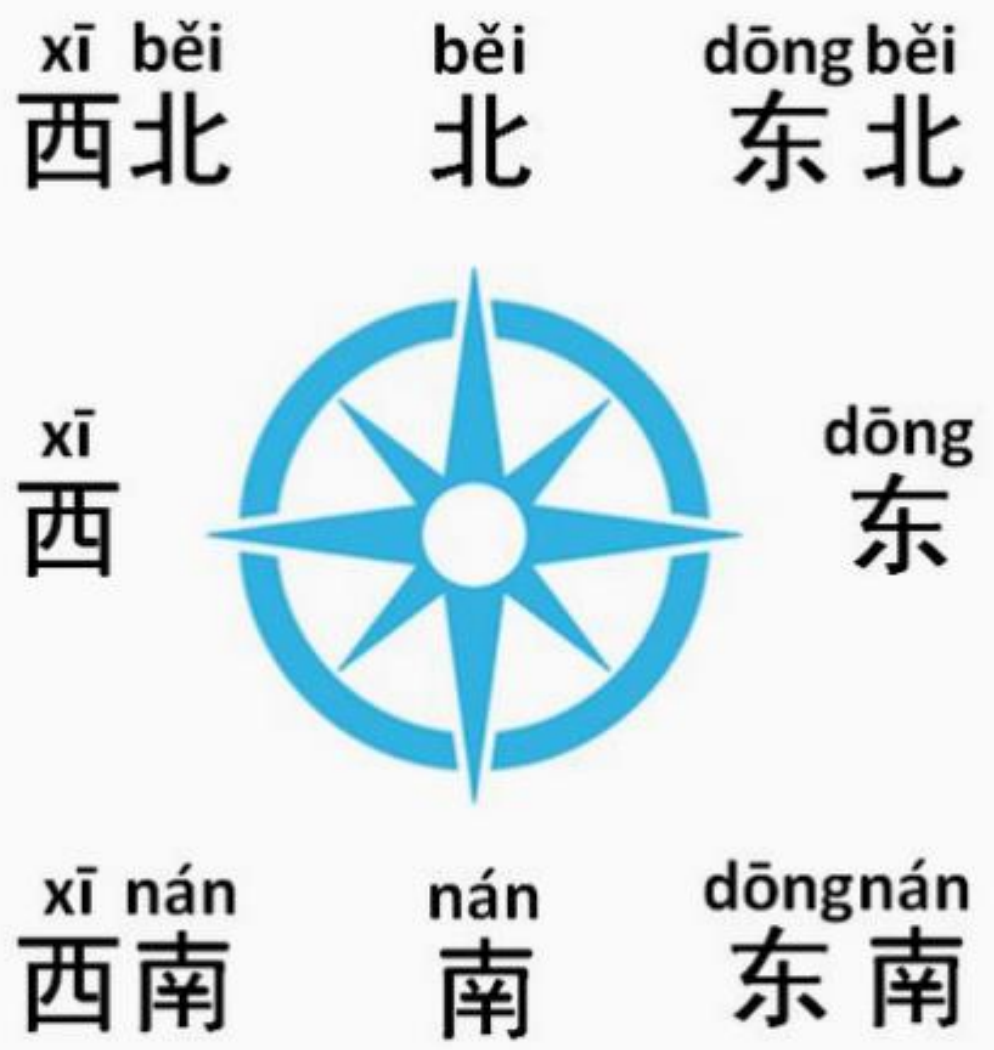

Gambar 3. Nama arah mata angin dalam bahasa Mandarin Sumber: (Sumber : http://wordoor-chinese.tumblr.com/) 


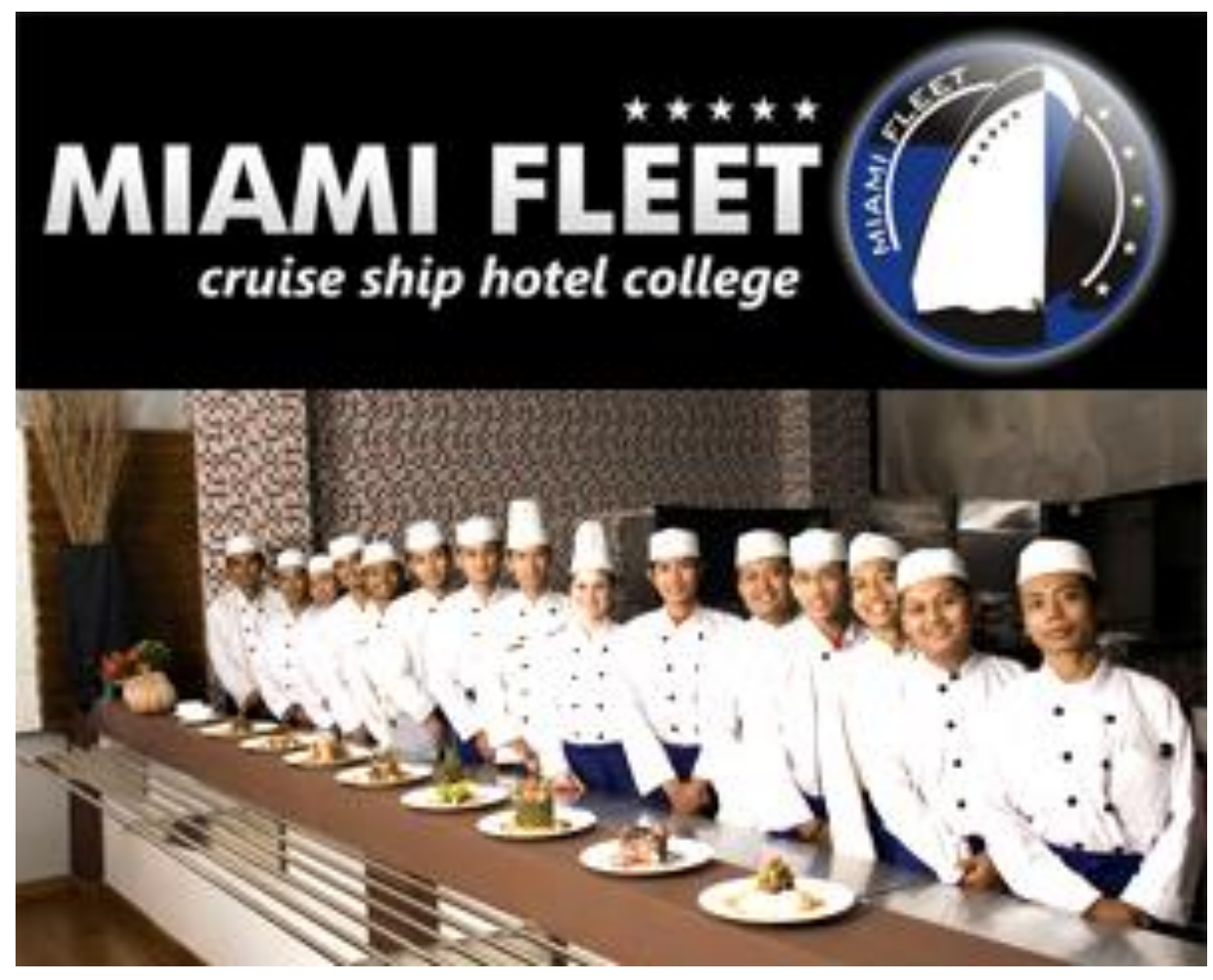

Gambar 4. Gambar siswa Miami Fleet Yogyakarta Sumber: www.jogjabagus.com 